\title{
STUDY CLIMATE AND IMPACT OF ICT IN CULTIVATION OF CROPS IN YAWAL TALUKA, KHANDESH REGION
}

\author{
Swati A. Patil ${ }^{1}$, Sonal P. Patil ${ }^{2}$ \\ ${ }^{1,2}$ G.H. Raisoni Institute of Engineering and Management, Jalgaon
}

\begin{abstract}
India is agriculture based country having two different conditions of farming and farmers due to natural irregularity now a day. Here in this project we are going to study the role of Information Communication Technology (ICT) in the development of farmers in Yawal Taluka in Khandesh region. Different ICTs are available for agriculture sector like SMS, Tele calling, TV, News letters, Magazines, call centers etc. After studying this we can conclude whether farmers are using available ICTs or not or whether there is problem in using these ICTs due to lack of infrastructure and facilities in villages.
\end{abstract}

Keywords : ICT, SMS, Tele Calling, Call Centers

\section{INTRODUCTION}

In the era of ICT, rapid changes are taking place at each and every place irrespective of core field of computers. Everybody is taking help of different ICTs to become successful in education field, social field, personal growth etc. Agriculture must not be exception of that. In India many schemes, websites, mobilesApps are developed for the benefits of farmers.

Indian agriculture is on the threshold of second revolution. So it is clear that next development will come from information and knowledge transfer in agriculture sector.

Agriculture is facing new and severe challenges in its own right With rising food prices that have pushed over 40 million people into poverty since 2010, more effective interventions are essential in agriculture. The growing global population, expected to hit 9 billion by 2050, has heightened the demand for food and placed pressure on already-fragile resources. Feeding that population will require a 70 percent increase in food production. So in future ICT will play a big and important role.

ICT in agriculture is an emerging field focusing on the enhancement of agricultural and rural development inIndia. It involves theapplication of innovative ways to useInformation \& Communication Technologies (ICT) in the rural domain. The advancements in ICT can be utilized for providing accurate, timely, relevant information and services to farmers, thereby facilitating an environment for more remunerative agriculture. Given the development scenario in Indian agriculture, the ICT movement is still evolving. [1]

In India government agencies like a network of ICAR ( Indian Council of Agriculture Research) agencies, or krishi vigyan centers, agriculture universities of different states provide the agriculture information. The responsibilities of these centers and agencies are to disseminate, refine and develop the latest technologies to farmers. Extensions activities are also carried out by state agriculture departments, private agro companies and NGOs[3].

India is developing country so in most developing country, agriculture is key economic factor [4].

On comparing to India's counter developing countries like China, Japan, etc. where advanced ICT technologies like IOT (Inter of Things) are being implemented in agriculture sector, in India still there is a long road ahead to travel. [6].

\section{ADVANTAGE OF ICT IN AGRICULTURE}

1. ICT opens an opportunity with networking of agriculture sector including researcher, farmers, experts, universities and all stakeholders of agriculture globally.

2. As everybody is having smart phones, via different Apps farmers can exchange their thoughts, new ideas with each other.

3. GIS (Geographical Information System) can also be one of the key factors for farmers since this system can help farmers to study about land, surrounding environment, which natural, artificial, transport resources are near by.

4. It can reduce risk factor by decision support system. 5.

III. SOME ICT PROJECTS IN AGRICULTURE IN MAHARASHTRA: [5]

Agmarknet Community Information Centers, Warana Wired Village Project of Maharashtra.

Some exclusive agriculture portals are Haritgyan.com, Krishiworld.net, Agriwatch.com Acquachoupal.com TOEHOLDINDIA.com ITC's Soyachoupal.com, and Plantersnet.com

\section{ICT IN THE FARMING CYCLE}

From farmer's point of view, the cropping stages typically go through three different stages namely pre cultivation, cultivation and harvesting and post cultivation. Pre cultivation includes crop selection, land selection, budget, and calendar definition. Actual crop cultivation and 
harvesting includes seed sowing, water management, fertilizers, pest management etc. Post harvesting includes marketing, transport, packaging, food processing, maintenance, time management etc. At these stages different Information communication technologies are used for example DSS (Decision Support System) GIS, ICT sensory and proximity devices, ICT enabled networking solutions, ecommerce m-commerce. Pest management includes use of pesticides and fertilizers to be used as per the climate. Water management includes water availability in the specific region and arrangement of water supply if required.

\section{METHODOLOGY}

To study use of ICT by farmers in Yawal Taluka, interview of farmers from targeted region is taken. So for this study, Opinion and interview technique is used. For this questionnaire is prepared and get it filled by farmers in the target region. Questionnaire is based on education, family background, type of crops, type of ICT used etc. Most of the questions are Yes or No type so that it is easy to question and answer. Different major regions are selected and visited their farms to see the crops.
First questionnaire is prepared and then various villages are visited and data is collected. From this data statistical analysis can be done to study the impact of ICT and other parameters directly or indirectly dependent on this survey. The regions visited are Padlase, Nhavi, Yawal, Kosgaon, Faizpur, Dahigaon, Sangavi, and Hingona.

\section{ANALYSIS}

After analysis of study it is observed that farmers in Yawal Taluka are doing very less use of modern ICTs like Internet. Most of the farmers only reads the magazines they subscribed but as per their opinion, though their experiment of cultivation of new crops are successful it is due to their personal experience or the experience form other farmers in local area or from other place. More surprising thing is that they know how to use WhatsApp but how to use internet they don't know rather they think information on Internet is only in English. Due to change in climate and profit farmers are now trying to take the new crops other than banana, Jawar like ginger, turmeric, potato, arvi, papaya.

Table 1. Statistical Report after Study

\begin{tabular}{|c|c|c|c|c|c|c|c|c|}
\hline Answer & $\begin{array}{c}\text { Secondary } \\
\text { Occupation }\end{array}$ & Consultancy & Award & $\begin{array}{c}\text { Next } \\
\text { Generation }\end{array}$ & New Crops & $\begin{array}{c}\text { Success of } \\
\text { New Crops }\end{array}$ & $\begin{array}{l}\text { Technical } \\
\text { Difficulty in } \\
\text { using ICT }\end{array}$ & $\begin{array}{l}\text { Improvement of } \\
\text { agri using ICT }\end{array}$ \\
\hline Yes & 17.91 & 10.44 & 1.31 & 41.79 & 55.22 & 29.85 & 38.80 & 61.19 \\
\hline NO & 82.08 & 89.55 & 98.50 & 58.20 & 8.95 & 35.82 & 62.20 & 38.81 \\
\hline
\end{tabular}

\section{CONCLUSION}

Though Information communication technology is widely used at different fields, its use in agriculture is limited due to illiteracy and lack of awareness modern ICT like mobileapps, websites, and portals. TV channels, newspaper are somewhat popular in targeted region. Most of the farmers believe on personal help from experienced, successful farmers, and elders for cultivation of crops. From this study it is observed that many ICTs are available in India but the use of it is very less and more important thing is that negligible amount of farmers have the knowledge about it. So it is more important to take awareness program and modern ICT handling camps for farmers about modern ICTs.

\section{ACKNOWLEDGEMENT}

Authors are grateful to North Maharashtra University (NMU) for this study under the Vice Chancellor Research Promotion scheme (VCRMS).

\section{REFERENCES}

[1]Interactive Information Dissemination System: Architecture For Disseminating Information To Farmers , A Newsletter Of The International Federation For Information Processing Working Group 9.4 And Centre For Electronic Governance Indian Institute Of Management, Ahmedabad, Volume 22, No. 2, July 2012
[2]ICT Solution Architecture For Agriculture, Fredrick AWUOR Et All , IIMC International Information Management Corporation, 2013 ISBN: 978-1-905824-39-7 [3] ICTS For Agricultural Extension: A Study In The Indian Himalayan Region, V.L.V. Kameswari Et Al., The Electronic Journal On Information Systems In Developing Countries, 2011

[4] Dial "A" for agriculture: a reviewof information and communication technologies foragricultural extensionin developing countries

[5] ICT Initiatives in Indian Agriculture Chitra B.M et.al, Volume 22, No. 3, November 2012 A Newsletter of the International Federation for Information Processing Working Group 9.4 and Centre for electronic Governance Indian Institute of Management, Ahmedabad

[6] Framework To Leverage Cloud For The Modernization Of The Indian Agriculture System , Hasteer, N. ; Sharma, M. ; Bansal, A.014 IEEE International Conference On Electro/Information Technology. 